TẠP CHÍ KHOA HỌC ĐẠI HỌC TÂN TRÀO

ISSN: $2354-1431$

http://tckh.daihoctantrao.edu.vn/

\title{
Ảnh hưởng của các hoạt động sinh kế đến công tác quản lý và bảo vệ rừng tại xã Thanh Tương, huyện Na Hang, tỉnh Tuyên Quang
}

\author{
Nguyễn Thị Hải ${ }^{a *}$, Trần Thị Thanh Vân ${ }^{a}$, Đặng Thị Phuoong ${ }^{a}$ \\ ${ }^{a}$ Trưòng Đại học Tân Trào \\ *Email: hainguyentq0495@gmail.com
}

\section{Thông tin bài viết}

Ngày nhận bài:

20/5/2019

Ngày duyệt đăng:

$10 / 6 / 2019$

Tù khoá:

Hoạt động sinh kế; công tác quản lý và bảo vệ rùng; bảo vệ và phát triển rùng

\section{Tóm tắt}

Kết quả nghiên cứu “Ảnh hưởng của các hoạt động sinh kế đến công tác quản lý và bảo vệ rừng tại xã Thanh Tương, huyện $\mathrm{Na}$ Hang, tỉnh Tuyên Quang" cho thấy, Thanh Tương là một xã có diện tích rừng lớn, do đó các hoạt động sinh kế của người dân ít nhiều cũng ảnh hưởng tới công tác quản lý và bảo vệ rừng. Các hộ gia đình tham gia hỗ trợ vào công tác bảo vệ và phát triển rừng như: trồng rừng, thông tin hay báo cáo tình hình về rừng, diễn biến, hành vi vi phạm đến rừng cho cán bộ quản lý và bảo vệ rừng để kịp thời có biện pháp xử lý và ngăn chặn. Ngoài những ảnh hưởng tích cực tới công tác quản lý và bảo vệ rừng, trong quá trình hoạt động sinh kế cũng đã gây nhiều khó khăn cho cán bộ quản lý như các hành vi phá rừng làm nương rẫy, săn bắt động vật trái phép...

Trên cơ sở phân tích đánh giá thực trạng kinh tế - xã hội tại địa phương và tình hình công tác quản lý bảo vệ rừng, đã xác định được các hoạt động sinh kế của cộng đồng dân cư tác động bất lợi đến tài nguyên rừng, đồng thời tìm ra các nguyên nhân để đưa ra các giải pháp cải thiện sinh kế của cộng đồng bao gồm: (1) Giải pháp về chính sách và pháp luật; (2) Giải pháp về kinh tế; (3) Giải pháp về khoa học kỹ thuật; (4) Giải pháp giáo dục tuyên truyền.

\section{1. Đặt vấn đề}

Thanh Tương là một trong bốn xã thuộc Khu Bảo tồn thiên nhiên Tát Kẻ - Bản Bung của huyện Na Hang, có tổng diện tích đất tự nhiên là 10.298,84 ha, gồm 13 thôn bản, 748 hộ, 3.340 khẩu với 11 dân tộc anh em chung sống. Xã Thanh Tương chủ yếu là đồi núi, người dân lại sống không tập trung, kinh tế chủ yếu phát sinh từ hoạt động nông lâm nghiệp với trình độ dân trí thấp, phương thức canh tác lạc hậu, kinh tế phát triển chậm, đời sống người dân còn nhiều khó khăn. Phát triển kinh tế lâm nghiệp của xã cũng như huyện Na Hang có ý nghĩa quan trọng đối với người dân và môi trường. Sinh kế là mối quan tâm hàng đầu của người dân trong xã, là điều kiện cần thiết cho quá trình phát triển nâng cao đời sống của người dân. Dưới sức ép của việc phát triển kinh tế đã làm cho tài nguyên rừng của xã Thanh Tương bị khai thác và sử dụng không hợp lý dẫn tới bị giảm sút về độ đa dạng sinh học. Bài toán mâu thuẫn giữa lợi ích của việc bảo tồn và phát triển kinh tế, vấn đề sinh kế cho cộng đồng dân cư trong xã vẫn chưa được giải quyết thỏa đáng. Để có thể bảo vệ rừng một cách bền vững thì những giải pháp đưa ra phải xuất phát từ thực tế địa phương, điều kiện sống của người dân cũng như vai trò của những bên liên quan đến công tác quản lí và bảo vệ rừng.

2. Đối tượng, thời gian, nội dung và phương pháp nghiên cứu

\section{1. Đối tự̆ng, phạm vi và thời gian nghiên cưu}

Đối tượng nghiên cứu: Các hoạt động sinh kế của cộng đồng dân cư

Phạm vi nghiên cứu: Nghiên cứu được tiến hành tại xã Thanh Tương, huyện Na Hang, tỉnh Tuyên Quang 
Thời gian nghiên cứu: từ tháng 01 năm 2018 đến tháng 5 năm 2018.

\subsection{Nội dung nghiên cúu}

Đánh giá điều kiện tự nhiên, kinh tế, xã hội tại xã Thanh Tương, huyện Na Hang, tỉnh Tuyên Quang.

Hiện trạng công tác quản lý tài nguyên rừng tại xã Thanh Tương, huyện Na Hang, tỉnh Tuyên Quang:

Ảnh hưởng của các hoạt động sinh kế đến công tác quản lí và bảo vệ rừng tại xã Thanh Tương, huyện $\mathrm{Na}$ Hang, tỉnh Tuyên Quang.

Đề xuất một số giải pháp phát triển sinh kế của người dân để làm tốt công tác quản lý, bảo vệ rừng.

\subsection{Phưong pháp nghiên cúu}

2.3.1. Phuoong pháp khảo sát thực địa và thu thập tài liệu

Phương pháp khảo sát thực địa: khảo sát thực địa tại xã Thanh Tương, huyện Na Hang, tỉnh Tuyên Quang, nhằm tìm hiểu sơ bộ về các mô hình sinh kế của cộng đồng người dân, trong đó ghi chép và chụp ảnh một số mô hình sinh kế. Dựa trên kết quả khảo sát thực địa tiến hành xây dựng phiếu điều tra.

Phương pháp thu thập tài liệu: Kết hợp khảo sát thực địa, thu thập tài liệu về kinh tế - xã hội của Ủy ban nhân dân huyện, xã. Báo cáo về hiện trạng rừng tại Phòng Tài nguyên và Môi trường huyện, Ban Quản lý Khu Bảo tồn thiên nhiên $\mathrm{Na}$ Hang. Ghi nhận về những vụ vi phạm pháp luật liên quan đến rừng tại UBND huyện, xã và Trạm Kiểm lâm xã. Thu thập tài liệu đã có liên quan đến các phương pháp và nội dung đang nghiên cứu, phân tích, lựa chọn các phương pháp nghiên cứu phù hợp.

\subsubsection{Phuoong pháp điều tra xã hội học}

- Xây dựng 02 mẫu phiếu điều tra về vấn đề bảo vệ rừng cho 02 đối tượng:

+ 01 mẫu phiếu điều tra dành cho nhà quản lí (tiến hành điều tra khoảng 10 người thuộc các đối tượng: Hạt kiểm lâm rừng đặc dụng $\mathrm{Na}$ Hang; Trạm kiểm lâm xã; Trưởng các thôn kiêm kiểm lâm viên...).

+ 01 mẫu phiếu điều tra dành cho cộng đồng dân cư (tiến hành điều tra khoảng từ 50 - 60 hộ gia đình).

Mục đích của việc điều tra nhằm thu thập thông tin, đánh giá về hiện trạng hoạt động sinh kế của cộng đồng, ảnh hưởng của các hoạt động sinh kế đến quản lý rừng, hiện trạng quản lý rừng của các cấp chính quyền, những thuận lợi và khó khăn trong quá trình quản lý, từ đó đề xuất các mô hình sinh kế và giải pháp quản lý phù hợp nhằm quản lý bền vững rừng huyện $\mathrm{Na}$ hang, tỉnh Tuyên Quang.

\subsubsection{Phương pháp phỏng vấn sâu}

Ngoài phiếu điều tra, sử dụng bảng hỏi để phỏng vấn sâu các nhà quản lý cấp huyện, xã nhằm đánh giá cụ thể về hiện trạng quản lý rừng, thuận lợi và khó khăn khi thực hiện. Đồng thời phỏng vấn sâu các hộ gia đình, các hoạt động sinh kế, thu nhập trung bình tháng, trung bình năm.

\subsubsection{Phuoong pháp tham vấn chuyên gia}

Tham vấn những chuyên gia có hiểu biết nhất định tại điểm nghiên cứu để có thể tìm hiểu, đánh giá khách quan về điều kiện tự nhiên, xã hội, môi trường ở khu vực nghiên cứu. Đồng thời, xin ý kiến của chuyên gia về nội dung liên quan đến giải pháp quản lý, phục hồi rừng, đề xuất các mô hình sinh kế bền vững.

\subsubsection{Phuoong pháp phân tích số liệu}

Phương pháp thống kê mô tả: từ kết quả điều tra, mô tả các hoạt động sinh kế của cộng đồng, các hoạt động sinh kế ảnh hưởng trực tiếp, gián tiếp và không ảnh hưởng đến rừng.

Phương pháp thống kê so sánh: từ những dữ liệu thu được, sàng lọc, phân tích dựa trên cơ sở lý luận để tổng hợp, so sánh dẫn chứng và giải quyết vấn đề.

\section{Kết quả nghiên cứu và thảo luận}

3.1. Hiện trạng công tác quản lý tài nguyên rùng tại xã Thanh Tương, huyện Na Hang, tỉnh Tuyên Quang

\subsubsection{Thực trạng quản lí và hoạt động bảo vệ rùng}

Kết quả khảo sát cho thấy, Thanh Tương là một xã có diện tích rừng tự nhiên lớn. Diện tích đất lâm nghiệp 9.413,52 ha, chiếm 91,6\% diện tích đất tự nhiên của toàn xã, trong đó diện tích đất có rừng $8.740,58$ ha, bao gồm: Rừng đặc dụng 3.944,19 ha, rừng phòng hộ $3.330,21$ ha, rừng sản xuất $1.359,48$ ha. Độ che phủ của rừng đạt $88,5 \%$.

\section{Kết quả thục hiện công tác quản lý và bảo vệ rùng}

Đã tổ chức tuyên truyền được 1.225 lượt người/26 cuộc; hình thức tuyên truyền thông qua hội nghị tại xã và các buổi họp thôn, ngoài ra tuyên truyền trên thông tin đại chúng như loa đài, pa nô, áp phích, phát tờ rơi. Phối hợp với Nhà trường tuyên truyền đến các cháu học sinh trong các giờ ngoại khóa số lượng: 299 học $\sinh / 13$ cuộc.

Thực hiện ký cam kết bảo vệ rừng giữa Chủ tịch xã với Chủ tịch huyện và giữa trưởng thôn (bản) với Chủ 
tịch xã đạt 100 \%, ký cam kết bảo vệ rừng giữa hộ gia đình với trưởng thôn (bản) hàng năm đều đạt trên $90 \%$.

Các tổ đội thực hiện nhiệm vụ bảo vệ rừng và phòng cháy, chữa cháy rừng từ xã đến thôn bản được kiện toàn. Công tác tuần tra, kiểm tra rừng tại các khu rừng trọng điểm, xung yếu được 593 lượt/32 tuyến.

Hàng năm tổ chức thành lập và kiện toàn 01 Ban chỉ huy về các vấn đề cấp bách trong công tác bảo vệ rừng và phòng cháy, chữa cháy rừng trên địa bàn xã. Ban chỉ huy gồm 23 thành viên do đồng chí Phó Chủ tịch Ủy ban nhân dân xã làm Trưởng ban. Ban hành Quy chế hoạt động và phân công trách nhiệm của các thành viên trong Ban chỉ huy. Tổ chức hội nghị chuyên đề bàn các giải pháp về công tác quản lý bảo vệ rừng, phòng cháy chữa cháy rừng và đất lâm nghiệp trên địa bàn xã.

Trong năm 2017 trên địa bàn xã Thanh Tương không xảy ra cháy rừng và lấn, chiếm đất lâm nghiệp, sử dụng sai mục đích. Kết quả thực hiện theo thông tư số 21/2016/TT-BNNPTNT quy định về khai thác chính và tận thu, tân dụng lâm sản năm 2017: 1.063,844 m³ trong đó:

- Rừng trồng tập trung: khối lượng khai thác $578,622 \mathrm{~m}^{3} / 12$ hộ/10,367 ha.

- Cây trồng phân tán: khối lượng khai thác 485,222 $\mathrm{m}^{3} / 30$ hộ.

Phối hợp cùng Ban Chỉ huy quân sự, Công an huyện $\mathrm{Na}$ Hang tổ chức thành công diễn tập Úng phó cháy rừng và tìm kiếm cứu nạn trên địa bàn xã. Kết quả đạt loại giỏi.

Năm 2017 lực lượng kiểm lâm đã xây dựng kế hoạch thường xuyên phối hợp với lực lượng Công an, Dân quân tự vệ và các đoàn thể chính quyền cấp xã, thôn bản, nhân viên hợp đồng tuần rừng tổ chức tuần tra, truy quét các tụ điểm khai thác, mua bán, vận chuyển lâm sản trái phép trên địa bàn xã đã phát hiện và xử lý cụ thể:

Bảng 1: Tình hình vi phạm xâm hại đến tài nguyên rùng tại xã Thanh tưong năm 2017

\begin{tabular}{|l|c|}
\hline \multicolumn{1}{|c|}{ Hành vi vi phạm } & $\begin{array}{c}\text { Số vụ } \\
\text { vi phạm }\end{array}$ \\
\hline Khai thác rừng trái phép & 02 vụ \\
\hline $\begin{array}{l}\text { Vi phạm các quy định chung của } \\
\text { Nhà nước về bảo vệ rừng }\end{array}$ & 01 vụ \\
\hline $\begin{array}{l}\text { Mua, bán, cất giữ, chế biến kinh } \\
\text { doanh lâm sản trái với quy định } \\
\text { của Nhà nước }\end{array}$ & 02 vụ \\
\hline
\end{tabular}

\begin{tabular}{|l|c|}
\hline Phá rừng trái pháp luật & 02 vụ \\
\hline $\begin{array}{l}\text { Vi phạm khác (không xác định } \\
\text { được chủ) }\end{array}$ & 10 vụ \\
\hline Tổng số: & $\mathbf{1 7}$ vụ \\
\hline
\end{tabular}

- Kết quả xử lý vi phạm: xử lý hành chính 17 vụ.

- Tang vật, phương tiện vi phạm:

+ Lâm sản: gỗ các loại từ nhóm III - VIII: 14,454 $\mathrm{m}^{3}$; gỗ thuộc loài nguy cấp quý hiếm nhóm IIA $=3,390$ $\mathrm{m}^{3}$; .

+ Tang vật: 02 máy cưa xăng

- Số tiền phạt vi phạm hành chính: 6.600 .000 đồng.

Nhận định các khu rừng thường xảy ra khai thác lâm sản trái phép gồm: Tát Lỏong, Bó Kim của thôn Bản Bung; Bành Ló thôn Yên Thượng; Khâu Tấu thôn Nà Coóc.

- Công tác phát triển rừng: trên địa bàn xã Thanh Tương năm 2017 trồng mới được 21,02 ha, trong đó rừng trồng tập trung 16,02 ha, cây trồng phân tán 5 ha.

3.1.2. Thuận lợi và khó khăn trong công tác bảo vệ rùng ơ địa phuơng

\subsubsection{Thuận lợi}

Trong năm 2017 công tác quản lý bảo vệ rừng trên địa bàn có những chuyển biến tích cực so với các năm về trước; tình trạng buôn bán, vận chuyển, khai thác, chế biến gỗ rừng tự nhiên, săn bắt động vật hoang dã chỉ diễn ra nhỏ lẻ tại một số thôn bản; so với năm 2016 (tổng số vụ vi phạm 25 vụ), năm 2017 giảm 08 vụ vi phạm.

- Công tác bảo vệ rừng, phòng cháy, chữa cháy rừng luôn được Đảng ủy, Ủy ban nhân dân huyện xã Thanh Tương, các ban - ngành đoàn thể và các cơ quan chức năng quan tâm, phối hợp chỉ đạo, tổ chức thực hiện.

- Hàng năm đều rà soát và hoàn thiện phương án bảo vệ rừng, tổ chức lực lượng, trang bị phương tiện tối thiểu phục vụ công tác bảo vệ rừng, phòng cháy, chữa cháy rừng. Trực kiểm tra, kiểm soát thường xuyên tại Trạm Kiểm lâm Thanh Tương và các chốt bảo vệ rừng.

- Thôn, bản đều quan tâm xây dựng mối liên kết, phối hợp chính quyền xã với lực lượng Kiểm lâm trong công tác bảo vệ rừng, phòng cháy và chữa cháy rừng.

\subsubsection{Khó khăn}

- Hầu hết các vùng rừng của xã đều tiếp giáp với khu vực dân cư, khu sản xuất nông nghiệp, có nhiều đường mòn đi lại của cư dân và xe cơ giới trong rừng. Do đó tình trạng khai thác, buôn bán, vận chuyển lâm 
sản trái phép; đốt nương làm rẫy ... rất khó kiểm soát. Vì vậy khả năng xâm hại tới tài nguyên rừng rất cao, việc quản lý nguồn lửa cũng vô cùng khó khăn.

- Lực lượng kiểm lâm và lực lượng xung kích bảo vệ rừng tại xã chưa được đầu tư trang thiết bị tương xứng để đáp ứng tốt cho công tác quản lý và bảo vệ rừng; thiếu các phương tiện đối phó với tình huống vi phạm của lâm tặc ngày càng tinh vi, hiện đại và khi xảy ra các vụ cháy rừng lớn.

- Mặt bằng dân trí, ý thức chấp hành pháp luật của người dân trong việc quản lý và bảo vệ rừng chưa cao; sản phẩm rừng hiện nay vẫn là nhu cầu cao của xã hội, do vậy những lúc thiếu hụt lương thực hay nông nhàn người dân thường vào rừng thu hái lâm sản, săn bắn thú rừng phục vụ nhu cầu tiêu dùng hàng ngày.

- Nhu cầu sử dụng lâm sản làm vật liệu nhà ở và chất đốt của người dân trong xã còn cao, trong khi điều kiện để thay thế vật liệu khác cũng rất hạn chế.

- Một số thôn bản thuần nhất một dân tộc, trong khi đó một số thôn bản khác lại xen lẫn các nhóm dân tộc với nhau, tập quán sinh hoạt theo cộng đồng, nên công tác tuyên truyền cũng có những đặc thù riêng.

- Trong những năm qua, một số khu rừng bị phá trước đây làm nương rẫy bỏ hoang đã lâu nằm cạnh rừng, không thực hiện các biện pháp phòng chống cháy rừng nên nguy cơ xảy ra cháy rất cao, nhất là vào những tháng mùa khô.

- Nguồn nước chữa cháy rừng chủ yếu từ sông, suối, ao hồ tại một số khu vực vào những tháng mùa khô thường bị cạn kiệt và cách xa rừng nên khi xảy ra cháy rừng việc dập lửa khó có thể thực hiện được.

- Cơ cấu phân 3 loại rừng trên địa bàn xã hiện nay chưa phù hợp, người dân chưa thể sống được bằng nghề rừng; việc giao đất, giao rừng cho hộ gia đình còn chậm nên một số mục tiêu, chính sách về phát triển rừng chưa thực sự đi vào cuộc sống.

3.2. Các nguồn vốn sinh kế của hộ gia đình, ảnh hương của các họ̣t động sinh kế đến công tác quản lý và bảo vệ rùng

\subsubsection{Các nguồn vốn sinh kế của hộ gia đình}

Vốn sinh kế của người dân vùng nông thôn gồm: Vốn con người, vốn xã hội, vốn tài chính, vốn vật chất và vốn tự nhiên.

\subsubsection{Vốn con người}

Bảng 2: Tình hình lao động tại xã Thanh Tưong năm 2016

\begin{tabular}{|l|r|r|}
\hline \multicolumn{1}{|c|}{ Dân số } & Số người & Tỉ lệ (\%) \\
\hline 1. Trong độ tuổi lao động & 1928 & 58 \\
\hline - Lao động nông nghiệp & 1695 & 51 \\
\hline - Lao động phi nông nghiệp & 233 & 7 \\
\hline 2. Ngoài độ tuổi lao động & 1421 & 42 \\
\hline Tổng & 3349 & 100 \\
\hline
\end{tabular}

Nguồn: Báo cáo kết quả thục hiện nhiệm vụ phát triển KT-XH, đảm bảo QP-AN xã Thanh Tưong năm 2016

- Lực lượng lao động tương đối đông. Dân số trong độ tuổi lao động chiếm tỉ lệ lớn số dân của toàn xã, đây là yếu tố thuận lợi cho việc phát triển ngành nghề, phát triển chăn nuôi hoặc phát triển các loại cây trồng yêu cầu sử dụng nhiều thời gian lao động.

- Lao động trẻ là yếu tố thuận lợi cho việc đào tạo văn hoá, chuyên môn và nâng cao thu nhập cho nông hộ. Đa số lao động ở địa phương là lao động trẻ, tập trung chủ yếu ở độ tuổi dưới 45. Lao động có độ tuổi từ 46 trở lên chiếm tỷ lệ thấp, đặc biệt là lao động ngoài 60 tuổi rất ít trong tổng số lao động thuộc các hộ điều tra.

- Lao động nông thôn chủ yếu vẫn là lao động nông nghiệp; tỷ lệ lao động phi nông nghiệp rất thấp, trong đó phần lớn là cán bộ địa phương, giáo viên, cựu chiến binh và cán bộ đã nghỉ hưu.

- Kết quả điều tra cho thấy, đa số lao động có trình độ từ trung học cơ sở trở xuống, lực lượng lao động có trình độ từ trung học phổ thông trở lên thấp, chủ yếu là các cán bộ của địa phương. Do vậy trình độ văn hoá và chuyên môn thấp của lực lượng lao động ở các điểm điều tra hiện nay đang là cản trở lớn đến việc tiếp nhận các loại khoa học kỹ thuật mới nhằm thâm canh tăng năng suất và chất lượng.

\subsubsection{Vốn xã hội}

Hội phụ nữ là tổ chức đem lại nhiều hoạt động thiết thực cho cộng đồng. Thanh niên chiếm tỷ lệ hơn $50 \%$ dân số nhưng hoạt động của Đoàn thanh niên lại mờ nhạt đối với cộng đồng dân tộc ít người, vì thanh niên dân tộc hay lập gia đình sớm, hoạt động kiếm sống chiếm hầu hết thời gian, bên cạnh đó nội dung của hoạt động Đoàn cũng chưa thu hút được thanh niên.

Mối liên hệ giữa cộng đồng với mạng lưới không chính thức được đánh giá rất cao, nhất là họ hàng và các tổ chức cộng đồng dân tộc anh em. Vai trò quan trọng của nhóm mạng lưới không chính thức còn thể hiện ở việc cung cấp thông tin cho cộng đồng. Các hộ kinh 
doanh nhỏ trong cộng đồng bao gồm người thu gom nông lâm sản, các đại lý bán vật tư, hộ bán nhu yếu phẩm cần thiết trong cộng đồng; phần lớn số người được phỏng vấn cho biết họ đã nắm thông tin về kỹ thuật sản xuất từ nguồn này.

\subsubsection{Vốn tài chính}

Vốn tài chính là các nguồn lực tài chính mà con người có được, như: nguồn thu nhập, các loại hình tiết kiệm, tín dụng và các nguồn thu nhập tiền mặt khác như lương hưu, tiền do người thân gửi về hay những trợ cấp của Nhà nước.

Những khó khăn về tài chính làm cho kinh tế nông hộ bị giảm sút, muốn cải thiện được kinh tế nông hộ thì việc tăng đầu tư nhằm mở rộng quy mô sản xuất, tăng năng suất và chất lượng sản phẩm là một nhu cầu tất yếu.

Trong điều kiện như hiện nay, khi mà khả năng tích luỹ của hộ nông dân cò thấp, sự hỗ trợ của Chính phủ và các tổ chức phi chính phủ ngày càng giảm, thì việc vay vốn để đầu tư được coi là quan trọng nhất để thoả mãn về mặt tài chính.

Có nhiều hộ nông dân vay được vốn, tuy nhiên vẫn còn có số ít các hộ không vay được. Lý do chủ yếu vẫn là: thủ tục còn rườm rà, phức tạp, thiếu sổ đỏ để thế chấp vay vốn và thời hạn vay ngắn... trong đó thời hạn cho vay ngắn được coi là rào cản lớn nhất đối với khả năng của nông hộ.

\subsubsection{Vốn vật chất}

Nguồn vốn vật chất được phân chia làm 2 loại: tài sản của cộng đồng và tài sản của hộ. Tài sản của cộng đồng trong nghiên cứu này xem xét các cơ sở vật chất cơ bản phục vụ nhu cầu sản xuất và sinh hoạt như: điện, đường giao thông, trường học, trạm $\mathrm{y}$ tế, công trình thủy lợi, thông tin liên lạc. Tài sản của hộ khá phong phú bao gồm cả các tài sản phục vụ sản xuất và các tài sản phục sinh hoạt của hộ.

Trong quá trình triển khai thực hiện Chương trình mục tiêu quốc gia về xây dựng nông thôn mới, xã Thanh Tương luôn nhận được sự quan tâm chỉ đạo, giúp đỡ và tạo điều kiện các cấp, các ngành từ tỉnh đến huyện, sự đồng tình ủng hộ của các tầng lớp nhân dân trong xã. Xã đã được cải thiện nhiều hệ thống đường giao thông, thuỷ lợi, xây dựng mới được trường học, trạm xá, nhà văn hoá thôn, xã, các các loại thiết bị giáo dục và y tế đã được bổ sung... nhờ đó mà việc đi lại của bà con nông dân đã bớt khó khăn, nhiều diện tích trước đây phải nhờ hoàn toàn vào tự nhiên, chỉ cấy, trồng được 1 vụ đến nay đã sản xuất được 2 vụ, hệ thống trường học và trạm y tế, nhà sinh hoạt cộng đồng được cải thiện cả về chất lượng và số lượng, cục diện nông thôn có những thay đổi rõ rệt.

Khi trao đổi với các hộ nông dân cho thấy, hầu hết đều mong muốn cải thiện hệ thống cơ sở hạ tầng với phương châm nhà nước và nhân dân cùng làm. Mặc dù điều kiện sống của người dân còn nhiều khó khăn nhưng họ vẫn sẵn sàng đóng góp sức người, sức của để xây dựng hệ thống cơ sở hạ tầng cho xã.

Hầu hết các chương trình, dự án đều tập trung vào hỗ trợ nguồn lực cho các hộ nghèo, đây là điều kiện thuận lợi để hộ nghèo tiếp cận với nguồn vốn vật chất và phát triển sản xuất.

\subsubsection{Vốn tự nhiên}

Vốn tự nhiên là các nguồn lực tự nhiên mà con người có quyền sử dụng gồm: đất sản xuất nông, lâm nghiệp, tài nguyên sinh vật, diện tích các ao hồ tự nhiên được phép khai thác. Trong đó, đất sản xuất nông, lâm nghiệp là nguồn vốn tự nhiên quan trọng nhất. Tuy nhiên, diện tích đất sản xuất nông nghiệp tại xã Thanh Tương không nhiều, chủ yếu là đất rừng đặc dụng, người dân ở đây thiếu đất để sản xuất nông nghiệp.

\subsection{2. Ảnh hương của các hoạt động sinh kế} đển rùng

Hoạt động phát rừng làm nương rẫy đã gắn liền với phong tục tập quán canh tác của đồng bào các dân tộc thiểu số, gây sức ép đến tài nguyên rừng.

Bảng 3: Một số hình thức sủ dụng đất rùng để sản xuất nông, lâm nghiệp

\begin{tabular}{|c|c|c|c|c|c|c|}
\hline \multirow[b]{2}{*}{ STT } & \multirow{2}{*}{$\begin{array}{c}\text { Hình thức } \\
\text { sử dụng } \\
\text { đất }\end{array}$} & \multirow{2}{*}{$\begin{array}{c}\text { Số hộ } \\
\text { phỏng } \\
\text { vấn }\end{array}$} & \multicolumn{2}{|c|}{$\begin{array}{c}\text { Số hộ thực } \\
\text { hiện }\end{array}$} & \multicolumn{2}{|c|}{$\begin{array}{c}\text { Số hộ } \\
\text { không } \\
\text { thực hiện }\end{array}$} \\
\hline & & & $\begin{array}{l}\text { Số } \\
\text { hộ }\end{array}$ & $\begin{array}{l}\text { Tỷ } \\
\text { lệ } \\
(\%)\end{array}$ & $\begin{array}{l}\text { Số } \\
\text { hộ }\end{array}$ & $\begin{array}{l}\text { Tỷ } \\
\text { lệ } \\
\text { (\%) }\end{array}$ \\
\hline 1 & Trồng ngô & 60 & 52 & 86,6 & 8 & 13,4 \\
\hline 2 & Trồng keo & 60 & 15 & 25 & 45 & 75 \\
\hline 3 & Trồng cam & 60 & 7 & 11,6 & 53 & 88,4 \\
\hline
\end{tabular}

(Nguồn: điều tra các hộ dân)

Qua bảng trên có thể thấy, hầu hết các hộ dân đều sử dụng đất rừng để sản xuất nông lâm nghiệp.

\subsubsection{Hoạt động khai thác lâm sản}

Từ bao đời nay rừng là nơi cung cấp nhiều sản phẩm phục vụ cho nhu cầu cuộc sống của người dân địa phương, bao gồm: 
- Khai thác gỗ để làm nhà ở, nhà kho, nhà sàn, chuồng trại chăn nuôi.

- Khai thác củi để phục vụ cho việc đun nấu, chế biến thức ăn hằng ngày, chế biến nông sản, sưởi ấm vào mùa đông giá lạnh.

- Khai thác các loại như măng, nấm, trái cây rừng, rau xanh dùng làm thức ăn hằng ngày, chế biến nông sản. Khai thác cây thuốc chữa bệnh thông thường; các loại tre nứa, song mây dùng đan lát vật dụng và làm nhà.

- Săn bắt các loại động vật như Sóc, Thỏ, Chim, Chuột, Rắn, Cá, Ếch,.... Bổ sung nguồn thực phẩm cho bữa ăn của gia đình.

Hoạt động khai thác lâm sản với mục đích hàng hóa: hoạt động khai thác các loại lâm sản với mục đích bán ra thị trường để thu về bằng tiền mặt phục vụ nhu cầu chi tiêu trong gia đình hoặc đem đổi lấy những mặt hàng cần thiết.

3.2.4. Hoạt động chăn thả gia súc và các hoạt động khác

Chăn nuôi gia súc theo phương thức thả rông trong rừng tự nhiên và rừng trồng đã trở thành thói quen của các dân tộc thiểu số ở nước ta. Điển hình như, tại thôn Đon Tâu xã Thanh Tương, gia đình ông Ma Văn Dũng chăn nuôi hơn 30 con trâu theo hình thức thả vào rừng tự nhiên.

Theo kết quả điều tra, khảo sát cho thấy có đến $96 \%$ số hộ dân sử dụng những sản phẩm như bao nilon gói thực phẩm, chai nhựa dẻo để đựng những thứ cần thiết khi sử dụng xong thường vứt lại trong rừng. Số lượng rác thải này rất khó phân hủy và gia tăng theo thời gian, do vậy sẽ gây ảnh hưởng đến môi trường rừng cây tái sinh và vi sinh vật trong đất. Đặc biệt nguy hại là việc sử dụng hóa chất để phun diệt cỏ trước khi làm đất trồng cây, dùng thuốc trừ sâu bệnh để phun cho cây trồng (lúa, bầu bí, đậu đỗ...), đây là nguyên nhân làm ảnh hưởng rất lớn đến môi trường nước và đất rừng, thảm thực vật, động vật và vi sinh vật rừng.

\subsubsection{Anh hương của các hoạt động sinh kế đến} công tác quản lí và bảo vệ rùng

Là một xã với diện tích rừng lớn và có nhiều hoạt động sinh kế liên quan đến rừng, vì vậy ít nhiều cũng ảnh hưởng tới công tác quản lý và bảo vệ rừng.

Các hộ gia đình trong xã là lực lượng tham gia hỗ trợ vào các công tác bảo vệ và phát triển rừng như: trồng rừng cho các dự án; thông tin, báo cáo tình hình về rừng, diễn biến, hành vi vi phạm đến rừng cho cán bộ quản lý và bảo vệ rừng trong xã để kịp thời có biện pháp xử lý và ngăn chặn.

Ngoài những ảnh hưởng tích cực tới công tác quản lý và bảo vệ rừng, trong quá trình hoạt động sinh kế cũng gây nhiều khó khăn cho cán bộ quản lý nơi đây như các hành vi phá rừng làm nương rẫy, săn bắt động vật trái phép...Trong đó với lực lượng 11 nhân viên bảo vệ rừng, 5 kiểm lâm thì không thể thường xuyên kiểm tra, tuần tra rừng ngăn chặn tận gốc các hành vi vi phạm lâm luật gây thiệt hại cho rừng.

\section{3. Đề xuất giải pháp sinh kế cho ngưòi dân tại xã Thanh Tương}

\subsubsection{Giải pháp về chính sách và pháp luật}

Ủy ban nhân dân xã cần làm tốt công tác quy hoạch và quản lý rừng có hiệu quả; phát triển cơ sở hạ tầng nông thôn cho xã, tạo điều kiện thuận lợi nhất để người dân khu vực phát triển kinh tế hàng hóa, nâng cao thu nhập.

Có cơ chế, chính sách thu hút các nguồn vốn từ các tổ chức ban ngành.

Đẩy mạnh xã hội hóa giáo dục, đa dạng các loại hình lớp, mở rộng quy mô nhà trẻ, nhóm trẻ khối trường mầm non. Quan tâm đầu tư cơ sở hạ tầng cho ngành giáo dục như xây dựng trường cao tầng, nhà điều hành, tăng cường đầu tư trang thiết bị đồ dùng phục vụ cho việc giảng dạy và học tập của học sinh.

Chính quyền địa phương cần tăng cường vai trò giám sát, chất lượng và giá cả của các đơn vị kinh doanh dịch vụ.

Nông dân cần tạo dựng mối quan hệ hợp tác tốt với các doanh nghiệp để thu mua, chế biến, tìm đầu ra cho sản phầm nông sản, đồng thời có những hỗ trợ về công nghệ và kỹ thuật trong quá trình sản xuất.

Tăng cường hơn nữa cho lực lượng kiểm lâm về nhân lực, trang thiết bị và phương tiện để làm tốt hơn nữa công tác quản lý và bảo vệ rừng.

\subsubsection{Giải pháp về kinh tế}

Đa dạng hóa các hoạt động sinh kế để nâng cao thu nhập: đẩy mạnh chuyển dịch hoạt động sản xuất nông, lâm nghiệp bán truyền thống sang thâm canh tăng năng suất, đồng thời phát triển các mô hình nông, lâm nghiệp mới phù hợp với điều kiện địa phương.

Tăng cường công tác tuyên truyền, vận động và hướng dẫn người dân; mạnh dạn chuyển đổi cơ cấu cây trồng, vật nuôi, ứng dụng các tiến bộ khoa học, kỹ thuật vào sản xuất. 
Tổ chức cho người trong độ tuổi lao động học nghề và đi lao động xuất khẩu, làm việc tại các khu công nghiệp trong và ngoài tỉnh.

Xây dựng và phát triển nhiều mô hình mẫu về phát triển kinh tế để nhân ra diện rộng; từng bước làm thay đổi tư duy, nhận thức và cách thức sản xuất của người dân.

Chuyển giao khoa học kỹ thuật cho sản xuất nông nghiệp thông qua hỗ trợ vốn vay ngân hàng.

Hỗ trợ vốn để phát triển cây trồng vật nuôi có hiệu quả kinh tế cao vì các hộ gia đình trong xã đều thiếu vốn để đầu tư phát triển sản xuất.

\subsubsection{Giải pháp kĩ thuật}

Cơ cấu tổ chức lại sản xuất nông, lâm nghiệp theo hướng tập trung, chuyên canh, chú trọng đổi mới phương thức canh tác, thâm canh tăng năng suất cây trồng; tập trung vào các cây trồng, vật nuôi chủ lực như: cây mía, cây bưởi, cam, con trâu, con bò, con dê, con lợn và gia cầm.

\subsubsection{Trồng trọt}

Bố trí cơ cấu giống hợp lý, tập huấn kỹ thuật thâm canh cây trồng vật nuôi đến từng thôn trên toàn xã. Tiếp tục duy trì và nâng cao hiệu quả trong công tác chăn nuôi, để nâng cao thu nhập cho người dân, đặc biệt là chăn nuôi trâu, bò, dê, gia cầm,...

Thường xuyên chỉ đạo cán bộ khuyến nông kiểm tra đồng ruộng, dự báo sâu bệnh hại cây trồng, hướng dẫn người dân các biện pháp phòng trừ sâu bệnh kịp thời có hiệu quả.

Phối hợp với phòng Nông nghiệp huyện Na Hang thường xuyên kiểm tra, hướng dẫn kỹ thuật cho người dân về chăm sóc, bảo vệ và nhân rộng dự án cây ăn quả (cây bưởi, cây vải, cây cam,...).

Tổ chức kiểm tra, rà soát toàn bộ diện tích hồ đập, công trình thủy lợi, để có biện pháp nâng hiệu quả sự dụng mặt nước, nước tưới phục vụ cho sản xuất nông nghiệp; quản lý chặt chẽ diện tích hồ đập hiện nay đã cho thuê đấu thầu theo quy định của pháp luật.

Giữ vững diện tích đất 2 vụ lúa để đảm bảo an ninh lương thực tại địa phương; xây dựng các mô hình sản xuất vườn rừng theo quy hoạch, thực hiện tốt công tác quản lý, bảo vệ rừng, gắn với bảo vệ môi trường và du lịch sinh thái, trồng và khai thác rừng hợ lý và bền vững.

\subsubsection{Chăn nuôi}

- Tiếp tục duy trì hiệu quả trong công tác chăn nuôi, để nâng cao thu nhập cho người dân, đặc biệt là chăn nuôi trâu, bò, dê, gia cầm.
- Đẩy mạnh công tác tiêm phòng đợt 2 cho đàn gia cầm, gia súc trên địa bàn xã, đảm bảo $100 \%$ theo kế hoạch đề ra.

- Phát triển đàn lợn, đàn gia cầm đạt chỉ tiêu kế hoạch huyện giao. Trong đó tập trung hỗ trợ nhân dân tiêm phòng định kỳ đàn gia cầm, gia súc, hỗ trợ kỹ thuận chăn nuôi, hỗ trợ giống và tìm đầu ra sản phẩm cho người dân.

- Thực hiện có hiệu quả các cơ chế, chính sách hỗ trợ sản xuất nông nghiệp, thúc đẩy phát triển các mô hình trang trại, tiêm phòng, phòng chống dịch bệnh; nâng cao hiệu quả chăn nuôi, tập trung phát triển đàn gia súc, gia cầm, gắn với quy hoạch xây dựng nông thôn mới.

\subsubsection{Giải pháp tuyên truyền giáo dục}

Nâng cao năng lực cán bộ các tổ chức, đoàn thể cấp thôn thông qua các lớp đào tạo, tập huấn về kiến thức khoa học, kỹ thuật, kỹ năng tiếp cận cộng đồng.

Tạo mối liên kết giữa người dân với chính quyền địa phương, giữa người dân với các doanh nghiệp, các hộ kinh doanh nhằm nâng cao năng lực tiếp cận thị trường của hộ gia đình.

Nâng cao chất lượng hiệu quả công tác khuyến nông, khuyến lâm, khuyến ngư. Làm tốt công tác định hướng đào tạo nghề cho lao động nông thôn; tuyên truyền, hướng dẫn để nông dân thay đổi nhận thức, cách làm ăn bằng các hình thức chuyển giao kỹ thuật và nâng cao kiến thức cho người dân.

Đầu tư xây dựng các mô hình trình diễn và các lớp học hiện trường về giống, mô hình Nông - Lâm kết hợp, kỹ thuật canh tác trên đất dốc, sử dụng bếp cải tiến hạn chế sử dụng củi đốt... tại các thôn trong xã để chuyển giao thiết bị khoa học kĩ thuật đến với người dân nhằm đảm bảo tính bền vững sinh thái; đồng thời nghiên cứu và chuyển giao các tiến bộ kỹ thuật, nâng cao năng suất cây trồng vật nuôi, năng suất lao động cho các hộ trong vùng.

\section{Kết luận}

Thực trạng sinh kế của người dân tại xã Thanh Tương là phát triển trồng trọt, chăn nuôi là chủ yếu, theo hình thức tự cung tự cấp trong hộ gia đình. Các nguồn vốn sinh kế của hộ gia đình gồm có: vốn con người, vốn tài chính, vốn xã hội, vốn tự nhiên và vốn vật chất.

Nghiên cứu đã cho thấy một số loại hình sinh kế có ảnh hưởng tiêu cực đến tài nguyền rừng như: khai thác gỗ, lâm sản ngoài gỗ, động vật hoang dã trái phép, khai thác thô các nguồn tài nguyên, phụ thuộc vào thiên 
nhiên. Thu nhập từ các loại cây ngắn ngày là nguồn thu chủ yếu của cộng đồng, song lại thấp và không ổn định do trình độ canh tác và đầu tư thấp, cơ cấu cây trồng tuy đã có những dịch chuyển theo hướng tích cực song vẫn chưa thực sự phù hợp, thiếu đất canh tác, thiên tai, dịch bệnh thường xuyên xảy ra. Nhiều tiềm năng của địa phương như chăn nuôi đại gia súc, kinh tế vườn hộ, khai thác và phát triển lâm sản ngoài gỗ chưa được phát huy một cách đúng mức. Đời sống của một bộ phận người dân trong vùng còn khó khăn vì vậy trở thành những người có tác động cao đến tài nguyên rừng trong khu vực. Đây là một vấn đề cho công tác quản lý bảo vệ rừng và công tác bảo tồn nguồn tài nguyên quý hiếm.

Trên cơ sở phân tích đánh giá thực trạng kinh tế - xã hội tại địa phương và tình hình công tác quản lý bảo vệ rừng khu vực, đã xác định được các hoạt động sinh kế của các cộng đồng dân cư tác động bất lợi đến tài nguyên rừng đồng thời tìm ra các nguyên nhân để đưa ra các giải pháp cải thiện sinh kế của cộng đồng bao gồm: (1) Giải pháp về chính sách và pháp luật; (2) Giải pháp về kinh tế; (3) Giải pháp về khoa học kỹ thuật; (4) Giải pháp giáo dục tuyên truyền.

Các giải pháp nêu trên cần được triển khai đồng bộ, linh hoạt và phù hợp với văn hóa tại địa phương mới đem lại hiệu quả cao.

\section{TÀI LIỆU THAM KHẢO}

1. Nguyễn Duy Thắng (2007), “Sư dụng vốn xã hội trong chiến luợc sinh kế của nông dân ven đô Hà Nộ duới tác động của đô thị hóa", Tạp chí Xã hội học, Số 4, tr. 37-47.

2. Nguyễn Văn Toàn (2012), “Ảnh huơng của chuoong trìn 135 đến sinh kế của đồng bào dân tộc it nguời huyện Huớng Hóa, tỉnh Quảng Trị”, Tạp chí khoa học, Trường Đại học Huế.

3. Trần Đức Viên, Nguyễn Quang Vinh, Mai Văn Thành (2005), Phân cấp trong quản lý tài nguyên rùng và sinh kế nguò̀i dân, Nhà xuất bản Nông nghiệp, Hà Nội.

4. Ủy ban nhân dân xã Thanh Tương (2016), Báo cáo thục hiện Chuoong trình mục tiêu quốc gia xây dựng nông thôn mới giai đoạn (2016-2020).

5. Ủy ban nhân dân xã Thanh Tương (2016), Báo cáo tiến độ, kết quả triển khai thực hiện Chuơng trình muc tiêu Quốc gia xây dưng nông thôn mói và công tác giảm nghèo trên địa bàn xã Thanh Tương năm 2016.

6. Ủy ban nhân dân xã Thanh Tương (2017), Báo cáo Kết quả thực hiện nhiệm vụ phát triển kinh tế - xã hội, đảm bảo quốc phòng - an ninh năm 2017; giải pháp phát triển kinh tế - xã hội, đảm bảo quốc phòng an ninh năm 2018.

\title{
Effects of living activities to the management and forest protection at Thanh Tuong commune, district of Na Hang, Tuyen Quang province
}

\author{
Nguyen Thi Hai, Tran Thi Thanh Van, Dang Thi Phuong
}

\section{Article info}

Recieved:

15/02/2019

Accepted:

$10 / 3 / 2019$

Keywords: Livingactivities; forest management and protection; forest protection and development

\begin{abstract}
Research results of "Effect of living activities to the management and forest protection at Thanh Tuong commune, Na Hang district, Tuyen Quang province shows that Thanh Tuong is a commune with large forest area. Therefore, the living activities of the people have affected the management and protection of forests. The families involved in protection and development forest such as: afforestation, giving information or reporting on the situation of forests, developments and violations to forests for forest management and protection staff to promptly take measures to handle and prevent. In addition to the positive impacts on forest management and protection, during the process of living activities, it has also caused many difficulties for management staff such as acts of deforestation for cultivation, illegal hunting of animals. ...

Based on the analysis and assessment of the local socio-economic situation and the situation of forest protection and management, livingactivities of the community have been identified to adversely affect forest resources., and find out the reasons for providing solutions to improve the living community, including: (1) Policy and legal solutions; (2) Economic solutions; (3) Scientific and technical solutions; (4) Education and propaganda solutions.
\end{abstract}

